\title{
SELECTION FOR THE DEVELOPMENT OF BLACK EYE COWPEA LINES ${ }^{1}$
}

\author{
JÉSSICA DANIELE LUSTOSA DA SILVA², KAESEL JACKSON DAMASCENO-SILVA ${ }^{3 *}$, MAURISRAEL DE \\ MOURA ROCHA ${ }^{3}$, JOSÉ ÂNGELO NOGUEIRA DE MENEZES JÚNIOR ${ }^{3}$, VALDENIR QUEIROZ RIBEIRO ${ }^{3}$
}

\begin{abstract}
Cowpea bean is a socioeconomically important legume that contribute to generate employment and income. This species presents great grain variability, and the commercial subclass black eye stands out as a very appreciated grain in Brazil and abroad, thus requiring the development of new cultivars. The objective of this work was to evaluate and select lineages of commercial black eye cowpea, based on simultaneous, and direct selection. First, 105 progenies and four controls were evaluated using the Federer's augmented block design. Seventy-seven progenies, selected from this evaluation-first selection cycle - and four controls were evaluated in three environments, using a simple $9 \times 9$ lattice design. Based on this evaluation, the second selection cycle was possible, resulting in 24 progenies. The gain by direct selection was lower than the predicted gain for grain yield in the first cycle, indicating that the selection was not effective. This result was probably due to the reduced genetic variability caused by the selection pressure. In the second cycle, the predicted and observed gains were similar, indicating that much of the expected gain was observed. The predicted and observed gains, with simultaneous selection based on the rank sum selection index, were similar in the first and second cycle. The simultaneous and direct selections resulted in genetic gains for grain yield in the two selection cycles, making it possible the selection of high grain yield lineages.
\end{abstract}

Keywords: Vigna unguiculata. Fradinho. Observed gain. Genetic gain.

\section{SELEÇÃO SIMULTÂNEA PARA DESENVOLVIMENTO DE LINHAGENS DE FEIJÃO-CAUPI DE PORTE ERETO E DO TIPO FRADINHO}

RESUMO - O feijão-caupi é uma leguminosa socioeconomicamente importante, contribuindo com a geração de emprego e renda. É uma espécie que apresenta grande variabilidade para o tipo de grão, sendo a subclasse comercial fradinho a que se destaca por ser um grão muito apreciado no Brasil e no exterior, demandando o desenvolvimento de novas cultivares. Este trabalho foi realizado com o objetivo de avaliar e selecionar linhagens de feijão-caupi tipo comercial fradinho, baseada na seleção simultânea e seleção direta. Inicialmente foram avaliadas 105 progênies e quatro testemunhas, utilizando o delineamento Blocos Aumentados de Federer. A partir desta avaliação foram selecionadas 77 progênies (primeiro ciclo de seleção), e quatro testemunhas que foram avaliadas em três ambientes, utilizando o delineamento látice simples 9x9. Fundamentado nessa avaliação, foi possível realizar o segundo ciclo de seleção, resultando em 24 progênies. Pela seleção direta, o ganho realizado foi inferior ao ganho predito para produtividade no primeiro ciclo, indicando que a seleção não foi efetiva, provavelmente devido à redução da variabilidade genética ocasionada pela pressão de seleção. No segundo ciclo, os ganhos realizado e predito foram bem próximos, indicando que grande parte do ganho esperado foi concretizado. Para os ganhos com a seleção simultânea baseados no Índice de Soma de Ranks, os valores de ganho predito e realizado foram semelhantes no primeiro e segundo ciclo. As seleções, simultânea e direta, possibilitaram a obtenção de ganhos genéticos para produtividade nos dois ciclos de seleção, possibilitando a seleção de linhagens de alta produtividade.

Palavras-chave: Vigna unguiculata. Ganho realizado. Ganho genético.

\footnotetext{
${ }^{*}$ Corresponding author

${ }^{1}$ Received for publication in $31 / 08 / 2016$; accepted in $05 / 18 / 2017$.

Paper approved from IV CONAC 2016.

Paper extracted from the master's thesis of the first author.

${ }^{2}$ Postgraduate Program in Genetics and Breeding, Universidade Federal do Piauí, Teresina, PI, Brazil; jessica.04lustosa@gmail.com.

${ }^{3}$ Embrapa Meio-Norte, Teresina, PI, Brazil; kaesel.damasceno@embrapa.br, maurisrael.rocha@embrapa.br, joseangelo.junior@embrapa.br, valdenir.queiroz@embrapa.br.
} 


\section{INTRODUCTION}

Cowpea (Vigna unguiculata (L.) Walp.) is a widely distributed legume plant worldwide, cultivated in about 97 countries. According to the FAO (FAOSTAT, 2016), the world production of cowpea in 2014, was approximately 5.6 million tons, over an area of 12.5 million hectares.

Cowpea has been a major food source for several populations around the world, especially in developing countries, standing out as a rich source of protein, and as an essential component of the world's agricultural production systems, especially in tropical dry regions (SINGH et al., 2002).

In Brazil, cowpea is cultivated mainly in the North, Northeast and Central-West regions, standing out as a crop of great socioeconomic importance and as one of the main components of the populations' diet in the North and Northeast regions. The cultivation of cowpea contributes to generate employment and income in both rural and urban areas (LIMA et al., 2007).

Cowpea presents great grain color variability, but there are several market niches for them, according to the consumer preference. The grain types were divided into four classes-White, Black, Colored and Mixed-and 17 subclasses (FREIRE FILHO, 2011). The black eye cowpea commercial subclass stands out because of its type of grain, very appreciated by the Brazilian consumer, and because it presents desirable characteristics for export. In spite of its importance in Brazil, the number of available cowpea cultivars from the commercial subclass black eye is still low, denoting the need for breeding to obtain new lineages with this type of grain.

Genetic improvements have provided continuous gains in grain yield over the years for various crops, such as maize, common beans and soybeans (ATROCH; NUNES, 2000). The genetic improvement of cowpea has significantly contributed to increase its grain yield, and to incorporate several characteristics that add value to this crop, such as the erect growth habit that allow mechanized harvesting (FREIRE FILHO, 2011).

The objective of breeding programs is to obtain cultivars that surpass the characteristics of the pre-existing ones. However, obtaining cultivars with these advantages is only possible if the new cultivar simultaneously have several phenotypes of interest, such as high grain yield and quality, plant growth habit that allows for mechanization, great resistance to pests and diseases, tolerance to high temperatures and water stress, good nutritional quality, great stability of production, and adaptation to different regions. The identification of superior genotypes based on only one character can lead to the failure of a cultivar, especially when economic and commercial characters, and the consumer preferences are not considered (CRUZ; REGAZZI; CARNEIRO, 2004). Simultaneous selection can be used as an efficient alternative to accelerate the breeding process, and can provide expressive genetic gains in different characters, since this selection is based on a single index obtained through multi-character information measured in the progenies/individuals.

Selection is an important step in genetic improvement that must be carried out as carefully as possible. Thus, in view of the complexity of simultaneous selection, selection indexes are used as an alternative for the identification of superior genotypes for different characters. According to studies conducted with simultaneous selection in cowpea (BERTINI et al., 2010; OLIVEIRA, 2014; DIAS, 2009; SANTOS; ARAÚJO, 2001), the most efficient selection indexes for this crop are the multiplicative index (SUBANDI; COMPTON; EMPIG, 1973) and the rank sum selection index (MULAMBA; MOCK, 1978).

The increase in the average performance of a population after each selection cycle, resulting from the increase in the frequency of favorable alleles, can be quantified by estimating the genetic gain. The estimation of the genetic gain allows the evaluation of the efficiency of the breeding techniques used, and guide the breeder to the development of superior populations (CRUZ; REGAZZI; CARNEIRO, 2004; FERH, 1987).

The objective of this work was to evaluate and select lineages of commercial black eye cowpea of erect growth habit, based on simultaneous, and direct selection.

\section{MATERIAL AND METHODS}

The progenies evaluated were from crosses between lineages from the Embrapa Mid-North Cowpea Breeding Program, and two cultivars - California Blackeye 27 (CB-27), from the Breeding Program of the University of California; and Vaina-Blanca (VB), from the National Institute of Agricultural Research (INIA) of Peru (Table 1). All the cowpea genotypes used as parents in the crosses were from the subclass black eye.

First, 105 progenies in the F5:6 generation and four controls - BRS Itaim, CB-27, Poços-de-Caldas-MG and Vaina-Blanca-were evaluated in a preliminary test in 2011 in Teresina PI, Brazil. The Federer's augmented block design (FEDERER, 1956) was used with five blocks, which consisted of 21 non-replicated treatments and 4 controls each. The experimental plot consisted of two $5.0 \mathrm{~m}$ rows spaced $1.30 \mathrm{~m}$ apart, with $0.25 \mathrm{~cm}$ between plants. 
J. D. L. SILVA et al.

Table 1. Codes of crosses and parents of the cowpea lineages evaluated.

\begin{tabular}{cc}
\hline Codes of crosses & Parents \\
\hline MNC06-895 & MNC01627F-5-1-1 ${ }^{(1)} \times$ CB- $27^{(2)}$ \\
MNC06-898 & MNC04-785B-79 ${ }^{(1)} \times$ CB- 27 \\
MNC06-901 & CB- 27 x MNC05-820B-173-2 $2^{(1)}$ \\
MNC06-907 & MNC05-820B-173-2 x VB ${ }^{(3)}$ \\
MNC06-908 & VB x MNC05-832B-230 \\
MNC06-909 & VB x MNC00-553D-8-1-2-3 ${ }^{(1)} \times$ CB-27 \\
\hline
\end{tabular}

Lineages developed by the: ${ }^{(1)}$ Embrapa (Brazilian Agricultural Research Corporation) Mid-North Cowpea Breeding Program. ${ }^{(2)}$ Breeding Program of the University of California.

${ }^{(3)}$ National Institute of Agricultural Research (INIA) of Peru.

After the evaluation in this preliminary test, 77 progenies were selected and evaluated in experiments using the $9 \times 9$ simple lattice design (intermediate test). The selection of progenies was performed considering mainly the characteristics 100-grain weight $(100 \mathrm{GW})$ and grain yield (GY). The intermediate tests were performed in 2011 in Teresina PI, Brazil, evaluating the F5:7 generation, and in 2012, in Teresina and Parnaíba PI, evaluating the F5:8 generation. The spacing used was $0.20 \mathrm{~m}$ between plants and $0.50 \mathrm{~m}$ between rows, with two plants per hole and plots consisted of two $5.0 \mathrm{~m}$ rows.

In 2013, 24 lineages selected in the intermediate test and two controls were evaluated in the value for cultivation and use (VCU) testing, in Teresina PI. The experimental design used was the randomized block with four replications. The plots consisted of four $5.0 \mathrm{~m}$ rows spaced $0.50 \mathrm{~m}$ apart, with $0.20 \mathrm{~m}$ between plants.

A similar conventional soil preparation consisted of plowing and harrowing was used in all experiments. The cultural practices were carried out according to the recommendations for the cowpea crop (ANDRADE JÚNIOR et al., 2002).

The following traits were evaluated in each plot: pod length (PL) - mean obtained by measuring (cm) ten pods randomly collected; weight of pods (PW) - total weight $(\mathrm{g})$ of ten mature pods randomly collected; number of grains per pod (NGP) - average of number of grains in ten pods randomly collected; grain weight per pod (GWP) - total grain weight (g) of ten mature pods randomly collected; 100-grain weight $(100 \mathrm{GW})$ - weight of one hundred grains sampled after the threshing of the pods; and grain yield (GY) - weight of all grains of the plot per unit area, expressed in $\mathrm{kg} \mathrm{ha}^{-1}$.

The data were subjected to residue analysis to verify the existence of discrepancies (outliers) between them, before the individual analyzes of variance. According to Santos et al. (2008), residue analysis involves standardized residues and adjusted value (predicted by the model) for each observation. The standardized residue (dij) is calculated by the equation: $d_{i j}=\frac{e_{i j}}{\sqrt{M S_{R e s}}}$, wherein eij is the residue resulting from the adjust to the chosen model, obtained by the expression $e_{i j}=\left[Y_{i j}\right.$ (observed) $-Y_{i j}$ (adjusted) $] ; \quad$ and MSRes is the mean square of the residue obtained from the analysis of variance of the model. The analysis of residues was performed using the SAS statistical program (SAS INSTITUTE, 2002).

The statistical model used for the preliminary test was:

$$
Y_{i j}=m+G_{i}+b_{j}+e_{i j}
$$

wherein, Yij is the value observed in the plot receiving the treatment $i$ in the replication $j$, with $i$ ranging from 1 to 105 and $\mathrm{j}$ ranging from 1 to $5 ; \mathrm{m}$ is the overall mean; $\mathrm{Gi}$ is the fixed effect of the treatments $\mathrm{i}(\mathrm{i}=1,2,3, \ldots, 109)$, the effect of genotype that can be decomposed into ti (fixed effect of the common genotypes $i$, with $i=1,2, \ldots, 4)$ and gi (fixed effect of non-common genotypes i, with $\mathrm{i}=1,2, \ldots, 105)$; bj is the effect of block $\mathrm{j}$ $(\mathrm{j}=1,2, \ldots, 5)$; and eij is the experimental errors of the observation Yij, assuming that they are independent and normally distributed, with mean zero and variance $\sigma 2 \mathrm{e}$.

The statistical model used for the intermediate test was:

$$
Y_{i j}=m+g_{i}+r_{j}+b_{k(j)}+e_{i j}
$$

wherein, Yij is the observed value of the plot receiving the treatment $i$ in the replication $j$, with $i$ ranging from 1 to 81 and $\mathrm{j}$ ranging from 1 to $2 ; \mathrm{m}$ is the overall mean; gi is the fixed effect of treatments $i$ ( $\mathrm{i}=1,2,3 \ldots 81) ; \mathrm{rj}$ is the fixed effect of the replication $\mathrm{j}(\mathrm{j}=1,2)$; bk $(\mathrm{j})$ is the effect of block $\mathrm{k}$ within the replication $\mathrm{j}$; and eij is the experimental errors of the observation Yij, assuming that they are independent and normally distributed, with mean zero and variance $\sigma 2 \mathrm{e}$.

The statistical model used for the VCU test was:

$$
Y_{i j}=m+G_{i}+b_{j}+e_{i j}
$$

wherein, Yij is the observed value of the plot receiving the treatment $i$ in the replication $j$, with $i$ ranging from 1 to 26 and $\mathrm{j}$ ranging from 1 to $4 ; \mathrm{m}$ is the overall mean; gi is the fixed effect of treatment $i$ $(i=1,2,3, \ldots, 26) ; b j$ is the effect of block $j(j=1,2$, $3,4)$; and eij is the average experimental errors of the plot ij, assuming that they are independent and normally distributed, with mean zero and variance $\sigma^{2} \mathrm{e}$. 
The predicted and observed genetic gains were estimated through direct selection and simultaneous selection. Estimates of genetic gain through direct selection were obtained by selecting the ten progenies that presented the highest averages for each of the individual characters. The rank sum selection index (MULAMBA; MOCK, 1978) was used to estimate the genetic gain through simultaneous selection, using a selection intensity of $15 \%$. The selection was carried out in two stages, related to the selection cycle. In the first cycle, predicted gains were estimated using the direct selection and simultaneous selection of progenies in the F5:6 generation (preliminary test) to obtain the F5:7 and F5:8 generations (intermediate test). In the second cycle, the predicted and observed gains were estimated through the direct selection and simultaneous selection of progenies in the F5:8 generation to obtain the F5:9 generation (value for cultivation and use test).

\section{RESULTS AND DISCUSSION}

The residue analysis showed presence of discrepant data in some traits. Thus, the data with abnormal residues were replaced by their respective predicted values to obtain homogeneity of variances and normality of residues, leaving them suitable for the subsequent analyzes of variance.

In the preliminary test, progenies F5:6 showed significant differences $(p<0.05)$ in grain weight per pod (GWP), grain yield (GY), 100-grain weight $(100 \mathrm{GW})$, pod weight $(\mathrm{PW})$ and number of grains per pod (NGP), indicating the existence of variability among the progenies and the possibility of success with selection (Table 2). The contrast between progeny and control was significant $(\mathrm{p}<0.01)$ only for $100 \mathrm{GW}$, denoting that the average progeny performance was different from the average performance of the controls. In this case, the progenies had mean $100 \mathrm{GW}$ higher than those of the controls; thus the progenies had larger grains than the controls (Table 2).

Table 2. Analysis of variance of 105 progenies of cowpea for the traits: pod length (PL), pod weight (PW), number of grains per pod (NGP), weight per pod (GWP), 100 grain weight (100GW) and grain yield (GY).

\begin{tabular}{cccccccc}
\hline \multirow{2}{*}{ Source of variation } & DF & \multicolumn{7}{c}{ Mean Square } \\
\cline { 3 - 8 } & & PL & PW & NGP & GWP & $100 \mathrm{GW}$ & GY \\
\hline Treatments & 108 & $2.55^{\mathrm{ns}}$ & $4.94^{* *}$ & $0.52^{\mathrm{ns}}$ & $0.04^{* *}$ & $8.30^{* *}$ & $331729.33^{* *}$ \\
Progenies (P) & 104 & $2.52^{\mathrm{ns}}$ & $0.04^{*}$ & $0.52^{*}$ & $0.04^{* *}$ & $7.32^{* *}$ & $266199.37^{* *}$ \\
Control (C) & 3 & $4.09^{*}$ & $0.14^{* *}$ & $0.26^{\mathrm{ns}}$ & $0.11^{* *}$ & $32.69^{* *}$ & $1766642.03^{* *}$ \\
P x C & 1 & $0.04^{\mathrm{ns}}$ & $0.01^{\mathrm{ns}}$ & $1.44^{\mathrm{ns}}$ & $0.03^{\mathrm{ns}}$ & $35.39^{* *}$ & $9455.13^{\mathrm{ns}}$ \\
Residue & 12 & $1.14^{\mathrm{ns}}$ & $1.21^{\mathrm{ns}}$ & $0.32^{\mathrm{ns}}$ & $0.01^{\mathrm{ns}}$ & $0.28^{\mathrm{ns}}$ & $53990.26^{\mathrm{ns}}$ \\
\hline CVg (\%) & - & 8.06 & 16.57 & 14.55 & 19.10 & 12.76 & 47.26 \\
$\mathrm{H}^{2}(\%)$ & - & 55.46 & 75.43 & 53.16 & 79.20 & 97.04 & 83.69 \\
CVg:CV (\%) & - & 1.11 & 1.75 & 1.07 & 1.95 & 5.72 & 2.27 \\
CVe (\%) & - & 7.22 & 9.43 & 13.5 & 9.72 & 2.25 & 20.93 \\
Mean of Progenies & & 14.80 & 1.17 & 4.16 & 1.05 & 23.51 & 1113.73 \\
\hline
\end{tabular}

$* *=$ Significant by the $\mathrm{F}$ test at $1 \%$ probability; *= Significant by the $\mathrm{F}$ test at $5 \%$ probability; $\mathrm{DF}=$ degrees of freedom; $\mathrm{H} 2$ = genotypic coefficient of determination; $\mathrm{CVg}=$ genetic coefficient of variation; $\mathrm{CVe}=$ experiment coefficient of variation; $\mathrm{CVg}: \mathrm{CVe}=\mathrm{CVg}$ to $\mathrm{CVe}$ ratio.

The estimates of the coefficient of genotypic determination $\left(\mathrm{H}^{2}\right)$ were: $97.04 \%(100 \mathrm{GW}), 83.69 \%$ (GY), 79.20\% (GWP), 75.43\% (PW), 55.46\% (PL), and $53.16 \%$ (NGP). High estimates for $\mathrm{H}^{2}$ may indicate genetic variability (TEIXEIRA et al., 2007). The estimates of $\mathrm{H} 2$ found in this work are consistent with those of other studies, confirming the high genetic variability of cowpea (CORREA et al., 2012; SILVA; NEVES, 2011).

The genetic coefficient of variation $(\mathrm{CVg})$ to experiment coefficient of variation $(\mathrm{CVe})$ ratio
(CVg:CVe), or selection potential of the test, was high mainly for GY and $100 \mathrm{GW}$, indicating that the selection may be effective for these characters (Table 2). Similar values were found by Costa et al. (2013). A high CVg:CVe indicates the existence of genetic variability among the progenies. $\mathrm{CVg}: \mathrm{CV}$ estimates equal to or greater than 1, indicates the possibility of obtaining significant genetic gains through selection (VENCOVSKY; BARRIGA, 1992).

Therefore, 77 out of the 105 progenies (F5:6) 
were selected as the most promising for grain yield, $100 \mathrm{GW}$ and cultivation value to be retested in three environments in 2011 and 2012. The analyzes of variance for the evaluated characteristics is presented in Table 3. The progenies presented significant differences $(p<0.05)$ for almost all characters in the three evaluated environments, indicating the existence of variability among them, which is determinant for the success of breeding programs, making it possible to select the progenies with better means (RAMALHO; SANTOS; PINTO, 2000).

Table 3. Analysis of variance and coefficients of variation of 81 genotypes of black eye cowpea for pod length (PL), pod weight (PW), number of grains per pod (NGP), grain weight per pod (GWP), 100 grain weight (100GW) and grain yield (GY) in three experiments carried.

\begin{tabular}{|c|c|c|c|c|c|c|c|}
\hline \multirow{3}{*}{ Source of variation } & \multirow{3}{*}{ DF } & \multicolumn{6}{|c|}{ Mean square } \\
\hline & & \multicolumn{6}{|c|}{ Teresina 2011} \\
\hline & & PL & PW & NGP & GWP & $100 \mathrm{GW}$ & GY \\
\hline Progenies $(\mathrm{P})$ & 76 & $1.38 * *$ & $0.17 * *$ & $1.74 * *$ & $0.07 * *$ & $5.54 * *$ & $310376.47^{* *}$ \\
\hline Control (C) & 3 & $1.65^{\mathrm{ns}}$ & $0.45 * *$ & $1.18^{\mathrm{ns}}$ & $0.04^{\mathrm{ns}}$ & $9.48 * *$ & $1088388.09 * *$ \\
\hline $\mathrm{P} \times \mathrm{C}$ & 1 & $1.57^{\mathrm{ns}}$ & $0.12^{\mathrm{ns}}$ & $1.22^{\mathrm{ns}}$ & $0.09^{*}$ & $3.47^{*}$ & $471385.11^{*}$ \\
\hline $\mathrm{RE}$ & & 100.60 & 101.51 & 103.67 & 107.31 & 143.35 & 108.44 \\
\hline $\mathrm{CV}(\%)$ & & 5.89 & 12.81 & 9.88 & 8.59 & 3.91 & 17.95 \\
\hline \multirow[t]{2}{*}{ Mean of progenies } & & 14.97 & 2.01 & 8.20 & 1.61 & 21.87 & 1844.68 \\
\hline & & \multicolumn{6}{|c|}{ Parnaíba 2012} \\
\hline Treatments & 80 & $1.78 * *$ & $0.13 * *$ & $1.97 * *$ & $0.08 * *$ & $3.78 * *$ & $400840.65 * *$ \\
\hline $\mathrm{RE}$ & & 101.46 & 120.83 & 131.67 & 100 & 103.48 & 155.59 \\
\hline $\mathrm{CV}(\%)$ & & 5.02 & 7.40 & 8.37 & 10.86 & 5.14 & 8.65 \\
\hline \multirow[t]{2}{*}{ Mean of progenies } & & 17.07 & 2.34 & 9.54 & 1.98 & 22.26 & 3080.65 \\
\hline & & \multicolumn{6}{|c|}{ Teresina 2012} \\
\hline Treatments & 80 & $4.08^{*}$ & $0.14 *$ & $2.50 *$ & $0.16^{* *}$ & $1.02 * *$ & $124086.41 * *$ \\
\hline Progenies (P) & 76 & $4.16^{*}$ & $0.13 *$ & $2.61 * *$ & $0.15^{* *}$ & $0.99 * *$ & $122785.83 * *$ \\
\hline Control (C) & 3 & $2.62^{\mathrm{ns}}$ & $0.24 *$ & $0.06^{\mathrm{ns}}$ & $0.27 *$ & $1.43^{*}$ & $215095.68 * *$ \\
\hline $\mathrm{P} \times \mathrm{C}$ & 1 & $0.92^{\mathrm{ns}}$ & $0.00^{\mathrm{ns}}$ & $0.50^{\mathrm{ns}}$ & $0.01^{\mathrm{ns}}$ & $0.00^{\mathrm{ns}}$ & $4228.38^{\mathrm{ns}}$ \\
\hline Effective Error & & $2.69^{\mathrm{ns}}$ & $0.09^{\mathrm{ns}}$ & $1.46^{\mathrm{ns}}$ & $0.08^{\mathrm{ns}}$ & $0.43^{\mathrm{ns}}$ & $36964.65^{\mathrm{ns}}$ \\
\hline
\end{tabular}

$* *=$ Significant by the $\mathrm{F}$ test at $1 \%$ probability; $*=$ Significant by the $\mathrm{F}$ test at $5 \%$ probability; $\mathrm{RE}=$ lattice relative efficiency; $\mathrm{CV}=$ experiment coefficient of variation.

In the test conducted in Teresina, in 2011, the contrast between progeny and control was significant for GWP, 100GW and GY ( $p<0.05)$, denoting the superior performance of the lineages in relation to the controls for these characters. PL, PW and NGP presented no significant differences for the contrast between progeny and control (Table 3 ).

In the the test carried out in Parnaíba in 2012, the progenies showed a significant difference for all the characters $(p<0.01)$, indicating that a selection of progenies may be efficient (Table 3). The contrast between progeny and control was significant for PL $(\mathrm{p}<0.01)$, PW $(\mathrm{p}<0.05)$ and GY $(\mathrm{p}<0.05)$, denoting that the average performance of the lineages was different from the average performance of the controls and for these characters. The progenies presented higher averages than the controls, proving that the progenies evaluated are promising for these characters. The GWP, NGP and $100 \mathrm{GW}$ presented no significant differences for the contrast between progeny and control, indicating that results of these characters was similar for the progenies and controls (Table 3 ).

In the test conducted in Teresina in 2012, considering the progeny as source of variation, there was a significant difference $(\mathrm{p}<0.01)$ for all characters evaluated, except for the contrast between progenies and controls, showing that the progenies was not significantly superior or inferior than the controls (Table 3 ).

In the intermediate test, the coefficient of variation ranged from 2.92 to 17.95 , results classified as low and medium, respectively (PIMENTEL GOMES, 2000) (Table 3). The CV values found in this study were similar to those found by Nunes et al. (2014), who evaluated 
irrigated black eye cowpea genotypes in different environments.

The 24 lineages (F5:9) and two controls evaluated in 2013 showed the significant effect of lineages $(p<0.01)$ in all evaluated characters, except PL (Table 4), indicating the possibility of success with selection. The contrast between progeny and control was significant for PW $(\mathrm{p}<0.05)$, GWP $(p<0.01)$ and GY $(p<0.01)$, indicating that the means of the lineages was different and lower than the means of the controls. This result is disadvantageous for the breeding process, since the purpose is to obtain superior genotypes than the control.

Table 4. Analysis of variance, coefficients of variation and estimates of genetic parameters of 26 cowpea genotypes for pod length (PL), pod weight (PW), number of grains per pod (NGP), grain weight per pod (GWP), 100-grain weight (100GW) and grain yield $(\mathrm{GY})$

\begin{tabular}{crcccccc}
\hline \multirow{2}{*}{ Source of variation } & DF & \multicolumn{7}{c}{ Mean Square } \\
\cline { 3 - 8 } & & PL & PW & NGP & GWP & $100 \mathrm{GW}$ & GY \\
\hline Treatments & 25 & $2.47^{\mathrm{ns}}$ & $0.20^{* *}$ & $1.90^{* *}$ & $0.15^{* *}$ & $9.06^{* *}$ & $949492.18^{* *}$ \\
Lineages (L) & 23 & $2.30^{\mathrm{ns}}$ & $0.17^{* *}$ & $1.89^{* *}$ & $0.12^{* *}$ & $9.17^{* *}$ & $939186.69^{* *}$ \\
Control (C) & 1 & $7.41^{*}$ & $0.74^{* *}$ & $3.55^{* *}$ & $0.61^{* *}$ & $15.21^{* *}$ & $490961.22^{\mathrm{ns}}$ \\
L x C & 1 & $1.38^{\mathrm{ns}}$ & $0.29^{*}$ & $0.51^{\mathrm{ns}}$ & $0.38^{* *}$ & $0.44^{\mathrm{ns}}$ & $1645048.25^{* *}$ \\
Residue & 75 & $1.54^{\mathrm{ns}}$ & $0.07^{\mathrm{ns}}$ & $0.86^{\mathrm{ns}}$ & $0.04^{\mathrm{ns}}$ & $0.45^{\mathrm{ns}}$ & $170014.89^{\mathrm{ns}}$ \\
\hline CVg (\%) & - & 2.55 & 6.57 & 5.12 & 6.63 & 6.76 & 192292.95 \\
$\mathrm{H}^{2}(\%)$ & - & 33.17 & 59.71 & 54.53 & 63.39 & 95.05 & 81.89 \\
CVg/CV (\%) & - & 0.35 & 0.61 & 0.55 & 0.66 & 2.19 & 1.06 \\
CV (\%) & - & 7.26 & 10.74 & 9.33 & 9.99 & 3.09 & 12.16 \\
Mean of progenies & & 17.10 & 2.45 & 9.92 & 2.08 & 21.85 & 3355.74 \\
\hline
\end{tabular}

$* *=$ Significant by the $\mathrm{F}$ test at $1 \%$ probability; $*=$ Significant by the $\mathrm{F}$ test at $5 \%$ probability; $\mathrm{DF}=$ degrees of freedom; $\mathrm{H}^{2}=$ genotypic coefficient of determination; $\mathrm{CVg}=$ genetic coefficient of variation; $\mathrm{CVe}=$ experiment coefficient of variation; $\mathrm{CVg}: \mathrm{CVe}=\mathrm{CVg}$ to $\mathrm{CVe}$ ratio.

The CVg:CVe was above 1.0 only for GY $(1.06 \%)$ and $100 \mathrm{GW}(2.19 \%)$, confirming the superiority of these characters, which also presented the highest CVg, 95.05 (100GW) and 81.89\% (GY) (Table 4).

The estimates of the genotypic coefficient of determination (H2) found in 2013 were expressive in all generations for GWP, GY and NGP, indicating a possible genetic progress with the selection of these characters (Table 4).

The first direct selection cycle had predicted gain (PSG) of $3.37 \%$ for PL, $12.06 \%$ for GY (representing $64.2 \mathrm{~kg} \mathrm{ha}-1$ ), $8.00 \%$ for $100 \mathrm{GW}$, $6.59 \%$ for GWP, and $6.07 \%$ for PW (Table 5).

The second cycle had PSG ranging from $1.58 \%$ (PL) to $10.24 \%$ (GY). Passos et al. (2011) evaluated the gain with the direct selection in cowpea and found PSG (\%) lower than 5\% for most characters; they concluded that the gains with the selection were slow.

For the first cycle with direct selection, the OSG for GY was 2.28, representing a gain of $4.56 \mathrm{~kg}$ ha- 1 . In the second cycle, the observed gain was 79.40 , representing a gain of $158.8 \mathrm{~kg}$ ha- 1 . The negative gains indicate losses during the selection process, and these losses occur when characters under selection are under strong environmental effect, or due to the reduction of the genetic variability, which is in general intrinsic to the selection process. The effects of the losses (negative gains) that occur during the selection process can be mitigated through a better management of the experiments to reduce environmental effects, and through the adoption of a more appropriate selection method.

The OSG was inferior to the PSG in the two selection cycles for all the characters. Moura (2013) also found OSG inferior to PSG. According to Frey and Horner (1955), the adoption of a more rigorous management for the experiments is necessary to make the observed gain as close as possible to the predicted gain, reducing the experimental errors and consequently the losses with the selection, especially for GY.

In addition to the PSG and OSG for each character, the selection gains were evaluated using the rank sum selection index (MULAMBA; MOCK, 1978) (Table 5). Selection based on a single character is in most cases inadequate because it can lead to unsatisfactory results for the others, however, it leads to a superior end product in relation to this character (CRUZ; REGAZZI; CARNEIRO, 2004). 
J. D. L. SILVA et al.

Table 5. Predicted selection gain (PSG) and observed selection gain (OSG) in two selection cycles by direct, and simultaneous* selection, with genotypes evaluated in preliminary, intermediate, and value for cultivation and use tests.

\begin{tabular}{|c|c|c|c|c|c|c|c|c|}
\hline \multirow{3}{*}{ Characters } & \multicolumn{8}{|c|}{ Gain with direct selection } \\
\hline & \multicolumn{4}{|c|}{$1^{\circ}$ Cycle } & \multicolumn{4}{|c|}{$2^{\circ}$ Cycle } \\
\hline & PSG & $\begin{array}{c}\text { PSG } \\
(\%)\end{array}$ & OSG & $\begin{array}{c}\text { OSG } \\
(\%)\end{array}$ & PSG & $\begin{array}{c}\text { PSG } \\
(\%)\end{array}$ & OSG & $\begin{array}{c}\text { OSG } \\
(\%)\end{array}$ \\
\hline PL & 0.54 & 3.37 & -0.42 & -2.20 & 0.27 & 1.58 & 0.20 & 3.62 \\
\hline PW & 0.14 & 6.07 & -0.07 & 68.90 & 0.12 & 4.81 & 0.07 & 4.45 \\
\hline NGP & 0.34 & 3.71 & 0.09 & 91.11 & 0.37 & 3.69 & -0.08 & 6.76 \\
\hline GWP & 0.13 & 6.59 & -0.01 & 56.39 & 0.11 & 5.12 & -0.02 & 4.20 \\
\hline GY & 64.2 & 12.06 & 2.28 & 189.16 & 85.87 & 10.24 & 79.4 & 53.81 \\
\hline $100 \mathrm{GW}$ & 1.77 & 8.00 & 1.61 & -11.89 & 1.24 & 5.69 & 0.94 & -4.14 \\
\hline \multirow{3}{*}{ Characters } & \multicolumn{8}{|c|}{ Gain with simultaneous selection } \\
\hline & \multicolumn{4}{|c|}{$1^{\circ}$ Cycle } & \multicolumn{4}{|c|}{$2^{\circ}$ Cycle } \\
\hline & PSG & $\begin{array}{c}\text { PSG } \\
(\%)\end{array}$ & OSG & $\begin{array}{c}\text { OSG } \\
(\%)\end{array}$ & PSG & $\begin{array}{c}\text { PSG } \\
(\%)\end{array}$ & OSG & $\begin{array}{c}\overline{\text { OSG }} \\
(\%)\end{array}$ \\
\hline PL & 0.35 & 2.16 & -0.38 & 3.57 & 0.39 & 2.27 & 0.60 & 7.81 \\
\hline PW & 0.11 & 4.96 & -0.05 & 72.77 & 0.13 & 5.44 & 0.08 & 7.31 \\
\hline NGP & 0.21 & 2.35 & 0.06 & 96.01 & 0.42 & 4.20 & 0.14 & 10.93 \\
\hline GWP & 0.10 & 5.23 & -0.05 & 69.53 & 0.12 & 5.98 & 0.02 & 7.58 \\
\hline GY & 16.08 & 3.02 & 23.26 & 295.76 & 12.86 & 1.53 & 59.94 & 54.65 \\
\hline $100 \mathrm{GW}$ & 0.52 & 2.35 & 0.08 & -5.91 & 0.75 & 3.45 & 0.44 & -0.47 \\
\hline
\end{tabular}

$\mathrm{PL}=$ pod length; $\mathrm{PW}=$ pod weight; $\mathrm{NGP}=$ number of grains per pod; $\mathrm{GWP}=$ grain weight per pod; $100 \mathrm{GW}=100$-grain weight; and GY = grain yield; *based in the index of Mulamba and Mock (1978).

In the first selection cycle, the OSG was negative for PL (-0.38), PW (-0.05) and GWP $(-0.05)$. The OSG estimates for NGP (0.06), GY (23.26) and 100GW (0.08) were positive, indicating that selection based on this index favored these characteristics, providing an increase in the frequency of favorable alleles. In the second selection cycle, all characters presented a positive gain (OSG), with higher OSG than those found in the first cycle, denoting the maintenance of genetic variability, since the obtaining of genetic gains was possible even after one selection cycle. This result is shown by the GSO found for GY in the first (23.26) and second selection cycle (59.94), which represents gains of $46.62 \mathrm{~kg}$ ha-1 and $119.88 \mathrm{~kg}$ ha-1 respectively.

In the second selection cycle, the observed gain were lower than the expected gain for almost all characters. Moura (2013) found similar results when comparing expected gain with observed gain in a study involving the selection of cowpea for extra-precocity.

\section{CONCLUSIONS}

The indirect selection through the number of grains per pod was efficient to obtain gains for grain yield.

From the direct selection, it was possible to obtain genetic gains for grain yield in the two selection cycles.

The simultaneous selection based on the rank sum selection index promoted higher observed than predicted gain percentages for grain yield.

\section{REFERENCES}

ANDRADE JÚNIOR, A. S. et al. Cultivo do feijão caupi (Vigna unguiculata (L.) Walp.). 2. ed. Brasília, DF: CNPTIA, 2002. 110 p.

ATROCH, A. L.; NUNES, G. H. S. Progresso genético em arroz de várzea úmida no estado do Amapá. Pesquisa Agropecuária Brasileira, Brasília, v. 35, n. 4, p. 767-771, 2000.

BERTINI, et al. Análise multivariada e índice de seleção na identificação de genótipos superiores de feijão-caupi. Acta Scientiarum Agronomy, Maringá, v. 32, n. 4, p. 613-619, 2010.

CORREA, A. M. et al. Estimativas de parâmetros genéticos e correlações entre caracteres fenológicos e morfoagronômicos em feijão-caupi. Revista Ceres, Viçosa, v. 59, n. 1, p. 88-94, 2012.

COSTA, E. M. R. et al. Genetic divergence among African cowpea lines based on morphoagronomic traits. Genetics and Molecular Research, Ribeirão Preto, v. 12, n. 4, p. 6773-6781, 2013.

CRUZ, C. D; REGAZZI, A. J. CARNEIRO, P. C. S. Modelos biométricos aplicados ao melhoramento genético. 3. ed. Viçosa, MG: Editora UFV, 2004. $480 \mathrm{p}$.

DIAS, F. T. C. Utilização de técnicas multivariadas e moleculares na caracterização e 
seleção de genótipos de feijão-caupi de porte ereto e ciclo precoce. 2009. 99 f. Dissertação (Mestrado em Agronomia: Área de Concentração em Fitotecnia) - Universidade Federal do Ceará, Fortaleza, 2009.

FAOSTAT. Data. Crops. Production quantities of cow peas, dry by country, 2014. Rome: FAO, 2016. Disponível em: <http://www.fao.org/faostat/en/ \#data/QC>. Acesso em: 30 mar. 2016.

FEDERER, W. T. Augmented (ou Hoonuiaku) designs. Hawaiian Planters' Record, Hawai, v. 55, n. 2, p. 191-208, 1956.

FERH, W. R. Principles of cultivar development: theory and technique. New York: Macmillan Publishing Company, 1987. v. 1, 563 p.

FREIRE FILHO, F. R. Feijão-caupi: produção, melhoramento genético, avanços e desafios. 1. ed. Teresina, PI: Embrapa Meio-Norte, 2011. 84 p.

FREY, K. J.; HORNER, T. Comparison of actual and predicted gains in barley selection experiments. Agronomy Journal, Madison, v. 47, n. 4, p. 186$188,1955$.

LIMA, C. J. G. S. et al. Resposta do feijão-caupi a salinidade da água de irrigação. Revista Verde de Agroecologia Desenvolvimento Sustentável, Mossoró, v. 2, n. 2, p. 79-86, 2007.

MOURA, R. M. Análise dialélica e de famílias de feijão-caupi visando seleção para extraprecocidade. 2013. 99 f. Dissertação (Mestrado em Genética e Melhoramento: Área de Concentração em Melhoramento de Plantas) Universidade Federal do Piauí, Teresina, 2013.

MULAMBA, N. N.; MOCK, J. J. Improvement of yield potential of the Eto Blanco maize (Zea mays L.) population by breeding for plant traits. Egyptian Journal of Genetics and Cytology, Cairo, v. 7, n. 1, p. $40-51,1978$.

NUNES, H. F. et al. Grain yield adaptability and stability of blackeyed cowpea genotypes under rainfed agriculture in Brazil. African Journal of Agricultural Research, Largos, v. 9, n. 2, p. 255$261,2014$.

OLIVEIRA, D. G. Seleção simultânea para produção, biofortificação e culinária em populações segregantes de feijão-caupi. 2014. $72 \mathrm{f}$. Dissertação (Mestrado em Genética e Melhoramento: Área de Concentração em Melhoramento de Plantas) - Universidade Federal do Piauí, Teresina, 2014.
PASSOS, A. R. et al. Ganho por seleção direta e indireta em caupi considerando a interação GxE. Revista da FZVA, Uruguaiana, v. 18, n. 1, p. 18-33. 2011.

PIMENTEL GOMES, F. Curso de estatística experimental. 14. ed. Piracicaba, SP: Editora da Universidade de São Paulo, 2000. 477 p.

RAMALHO, M. A. P.; SANTOS, J. B.; PINTO, C. A. B. P. Genética na Agropecuária. 7. ed. São Paulo, SP: Editora Globo, 2000. 359 p.

SANTOS, C. A. F.; ARAÚJO, F. P. Aplicação de índices para seleção de caracteres agronômicos de feijão-de-corda. Ciência Agronômica, Fortaleza, v. 32 , n. $1 / 2$, p. $78-84,2001$.

SANTOS, J. W. et al. Estatística experimental aplicada. 2. ed. Campina Grande, PB: Embrapa Algodão, 2008. 461 p.

SAS INSTITUTE. SAS 9.2 Software. SAS Institute, 2002. Disponível em: <http://support.sas.com./ software/92/>. Acesso em: 30 ago. 2016.

SILVA, J. A.; NEVES, J. A. A. Componetes de produção e suas correlações em genótipos de feijãocaupi em cultivo de sequeiro e irrigado. Revista Ciência Agronômica, Fortaleza, v. 42, n. 3, p. $702-$ $713,2011$.

SINGH, B. B. et al. Recent progress in cowpea breeding. In: FATOKUN, C. A. et al. (Eds.). Challenges and opportunities for enhancing sustainable cowpea production. Ibadan: International Institute of Tropical Agriculture, 2002. p. $22-40$.

SUBANDI, W.; COMPTON, A.; EMPIG, L. T. Comparison of the efficiencies of selection indices for three traits in two variety crosses of com. Crop Science, Madison, v. 13, n. 2, p. 184-186, 1973.

TEIXEIRA, N. J. P. et al. Produção, componentes de produção e suas interrelações em genótipos de feijãocaupi [Vigna unguiculata (L.) Walp.] de porte ereto. Revista Ceres, Viçosa, v. 54, n. 314, p. 374-382, 2007.

VENCOVSKY, R.; BARRIGA, P. Genética biométrica no fitomelhoramento. 1. ed. Ribeirão Preto, SP: Sociedade Brasileira de Genética, 1992. $496 \mathrm{p}$. 